\title{
Short Article
}

\section{Notes on Ancient Greek \#o-}

\author{
Eric P. Hamp \\ University of Chicago
}

The following notes on various Ancient Greek words with initial ó-, as discussed in Frisk 1963 (henceforth, $G E W$ ), clarify aspects of the development of this vowel in Greek.

$G E W 352-3$, s.v. ó $\omega^{\prime} v$ (Ion.) 'tooth' has a fine account of the Greek as far as it went at the time of publication of his work (1963). Beyond the Greek, as it turns out (especially for the Armenian, Latin, and ultimately Lithuanian), the total Indo-European history is far simpler, richer, and more instructive than it seemed then. At that time, only separate details were noted in isolation, e.g. "ablaut" without motivation. Thus Armenian atamn, an ancient participle, did not show secondary vocalization in the initial vowel, but together with Greek ódov $\tau$ - (see Hamp 1978) rather simply regular vocalization of initial pre-consonantal Schwundstufe *2-, hence ${ }^{*}$ ?d-. This laryngeal $\left({ }^{*}\right)$ disappeared regularly in Indic, Lithuanian, German: *2dónt-, and Indic, Latin, Old

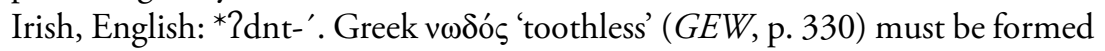
somewhat later, when *ve- would merge with od-<*odo-<*?dónt-, because $v \omega \delta$ ó $\varsigma$ means 'zahn-los' and not 'ess-los' or 'aß-los'.

övo $\mu \alpha$ 'name' as a headword is justified by its presence but $G E W$ should note that it is restored from derivatives. That is shown by the by-form हैvv $\mu \alpha$, which has the regular o $>v$ between nasal and labial and thus no *?- $>0$ assimilated to -o- in a following syllable. óvo $\mu \alpha$ as discussed in GEW 396-7 is excellent except for two points. The Latin form (nömen) does not equate to Indic namma in length; rather, Indic must be explained by Brugmann's Law $\left({ }^{*} \mathrm{o}>\bar{a} / \mathrm{R} \_\mathrm{CV}\right)$ and Latin must, by Warren Cowgill's genius, by a cross with *gnōmen. Greek vóvvuvos 'nameless' can be later, with - $\omega$ - from $\varepsilon$-o- after 
colouring of ${ }^{*}$ ?, which is assured by Old Prussian emmens 'name'; ${ }^{1}$ Tosk Albanian emër 'name' must show e- via umlaut from *a < syllabic *n.

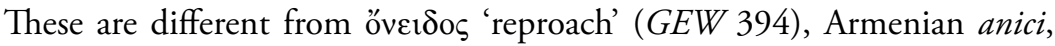
apparently with ${ }^{*} f^{\mathrm{w}} \mathrm{n}$-, and óv $\alpha \rho$ 'dream' and Armenian anurj, Geg Albanian

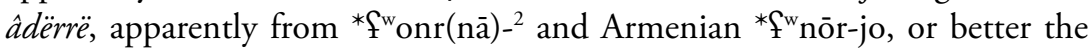
latter from earlier ${ }^{*}{ }^{w} n \underline{n}+-$-jo-, or more exactly ${ }^{*}{ }^{*}{ }^{w} n \underline{r} H_{a}+$. The last fits with what I have proposed for Helleno-Armenian as seen in Greek ï $\delta \omega \rho$ 'water' (see Hamp 1983-84, 1990).

Finally, regarding ỏ $\beta \lambda_{0-} \sim$ ó $\delta \varepsilon \lambda_{0}-$ 'spit', GEW (s.v.) has $\beta \varepsilon \lambda$ - but ỏ- "unerklärt”. I compare Albanian hell 'spit' < * $\mathrm{h}_{4} \mathrm{og}^{\mathrm{w}} \mathrm{e} / \mathrm{olo}-\left(>\mathrm{hag}{ }^{(\mathrm{w})} \mathrm{e}-\mathrm{i} / \mathrm{ała}->\right.$ hät- (cf. qen 'dog' < cann- and qelq 'glass' < calice-, both borrowed from Latin)), as well as halë 'fishbone' $<{ }^{*} \mathrm{~h}_{4} \mathrm{og}^{\mathrm{w}} \mathrm{e} / \mathrm{o}-\mathrm{l}-\mathrm{n}(\mathrm{o})-\overline{\mathrm{a}}$ (where $-\bar{a}$ is the collective suffix). ${ }^{3}$

\section{References}

Frisk, Hjalmar. 1963. Griechisches etymologisches Wörterbuch. Heidelberg. [GEW]

Hamp, Eric P. 1978. On Greek "Prothetic" Vowels. Münchener Studien zur Sprachwissenschaft 37: 59-64.

Hamp, Eric P. 1983-84. Final *Liquid + Laryngeal in Greek. Glossología 2-3:163-8.

Hamp, Eric P. 1990. Three Armenian Sound Laws. Annual of Armenian Linguistics 11: 21-3.

Hamp, Eric P. 2008. Notes on Continental Celtic and Indo-European: 2. Gaulish CVRMI,

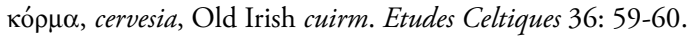

${ }^{1}$ Cf. Hamp 2008, on Gaulish anman 'name'.

2 Giving *án(d)rinā > *ándrnā > *âd(ë)rrā, with North European *o > *a.

${ }^{3} \mathrm{On}^{*} \mathrm{~h}_{4} \mathrm{o}-$, cf. ỏ $\lambda_{1} \sigma \theta \alpha \dot{\alpha} v \omega$ 'slide'. 